\title{
ESTILO ACADÊMICO E ESTILOS INDIVIDUAIS EM TRABALHOS DE CONCLUSÃO DE CURSO DE LETRAS: IMPLICAÇÕES PARA O ESTUDO DOS LETRAMENTOS ACADÊMICOS
}

\section{ACADEMIC STYLE AND INDIVIDUAL STYLE IN FINAL PAPER UNDERGRADUATE OF LETTERS: STYLE IMPLICATIONS FOR THE LITERACY ACADEMY STUDIES}

Willian Mainardes Waiga*

Pascoalina Bailon de Oliveira Saleh **

\begin{abstract}
Resumo: O comportamento dos textos acadêmicos pode ser compreendido a partir de dois fatores diametralmente opostos, porém, copresentes nos textos. Tratase de fatores geradores de estabilidade, contíguos ou paralelos a fatores criativos geradores de transformação. Nesse sentido, este trabalho, que faz parte de um estudo mais amplo que visa a investigar formas de inscrição da subjetividade nos gêneros acadêmicos resultantes de Trabalhos de Conclusão de um curso de Letras do Paraná, busca depreender as relações de poder nos resumos de gêneros acadêmicos, artigos, monografias e ensaios, do ponto de vista estilístico à luz das perspectivas enunciativa e discursiva, ancoradas num entendimento dialógico da linguagem. A metodologia adotada é a pesquisa qualitativa de tipo documental. O corpus consiste de 46 resumos de TCCs defendidos em 2018. Os principais resultados indicam que o estilo acadêmico não se apresenta homogêneo, mas repleto de imbricações resultantes dos confrontos entre subjetividade, linguagem e poder.
\end{abstract}

Palavras-chave: Letramento acadêmico; TCC; subjetividade.

Aвstract: The behavior of academic texts can be understood from two diametrically opposed factors, however, copresents in the texts. These are factors that generate stability, contiguous or parallel to creative factors that generate transformation.

\footnotetext{
"Mestre em Estudos da Linguagem (2020, UEPG), possui graduação em Licenciatura em Letras português/inglês (2015, UEPG). E-mail: wmwaigam@gmail.com.

"* Professora do Departamento de Estudos da Linguagem do Setor de Ciências Humanas, Letras e Artes da Universidade Estadual de Ponta Grossa (UEPG). E-mail: pbosaleh@gmail.com.
} 
In this sense, with the present study, which is part of the broader study that aims to investigate ways of subjectivity inscription in academic genres resulting from the Final Paper of Undergraduate in Letters from Paraná, we seek to catch the power relations in abstracts of academic genres, articles, monographs and essays, under a stylistic approach in the light of the perspective of literacies, discourse and enunciation, anchored in a dialogical understanding of language. The methodology adopted is qualitative research of documentary type. The corpus consists of 46 abstracts of TCCs defensed in 2018. The main results indicate that the academic style is not homogeneous, but full of imbrications resulting from the confrontations between subjectivity, language and power.

KEYwoRDs: Academic literacy; Final paper undergraduate; subjectivity.

\section{INTRODUÇÃo}

Neste trabalho, analisamos as relações entre poder e estilo nos resumos de Trabalhos de Conclusão de Curso - doravante TCCs - dos alunos de um curso de Letras de uma universidade pública do Paraná. O estudo é parte de um trabalho de dissertação de mestrado, no qual são investigadas as diversas formas de inscrição da subjetividade na escrita acadêmica, de modo a atrelar as perspectivas enunciativa e discursiva a questões de letramento, desde uma orientação dialógica de linguagem.

Ao atualizarmos o recorte nos termos deste estudo, nos voltamos para a relação entre poder e estilo nos resumos, nosso foco são os "processos não subjetivos de individuação" (SIGNORINI, 2010) como forças coercitivas atuantes na escrita acadêmica, oriundas de vetores das mais diversas ordens e naturezas. Algumas são mais evidentes, outras mais apagadas/ diluídas, contudo não menos atuantes. Entre as mais evidentes, encontram-se aqueles vetores relativos a processos de normalização da escrita, tais como a ABNT - Associação Brasileira de Normas Técnicas, o Regulamento do TCC do curso de Licenciatura em Letras da instituição lócus desse estudo, bem como as prescrições dos mais diversos manuais de escrita acadêmica. Outras podem ser tomadas como sendo intrínsecas ao gênero ou a como o gênero deveria estar configurado, segundo discursos que o submetem a critérios de cientificidade, objetividade, impessoalidade e neutralidade em formas cristalizadas assim reconhecíveis.

Tais discursos circulam na esfera acadêmica e alcançam/interpelam o(a) acadêmico(a) de maneiras complexas, sendo suas diretrizes muitas vezes incorporadas por eles em suas práticas sociais discursivas. Dentre esses meios, citamos o currículo. Este, embora não seja responsável por veicular ideologias que apregoam isenção e neutralidade na escrita acadêmica, é responsável pela estrutura disciplinar do curso, por meio da qual os acadêmicos recebem/ constroem seu letramento acadêmico. Essa estrutura curricular, que é bastante flexibilizada, molda, ao menos em parte, aquilo que os(as) acadêmicos(as) compreendem por escrita de um 
texto acadêmico, o que, por sua vez, se refletirá dialogicamente em suas produções. Ou seja, TCCs concebidos enquanto indicativos de processos de letramento na universidade.

Esses discursos, dentre outros, não necessariamente alinhados entre si, que povoam o curso de Letras da instituição no que se refere à escrita acadêmica, acessam os(as) estudantes por meio de enunciados que circulam nas aulas, proferidos por professores(as) e presentes nos textos lidos pelos acadêmicos. Some-se a isso os discursos constitutivos das representações dos acadêmicos sobre escrita (de modo geral) e cientificidade (escrita acadêmica de modo específico) que precedem o curso de graduação e circulam no mundo da cultura e da sociedade nos contextos escolares dos quais os estudantes são oriundos.

Esses fatores se refletem naquilo que Corrêa (1997) denominou três eixos de representação da escrita. Segundo o autor, o escrevente faz representações sobre o que imagina ser a gênese da sua própria escrita, sobre o que imagina ser o código escrito institucionalizado (escrita acadêmica e gêneros acadêmicos), e sobre a dialogia com o já falado/escrito e com o já ouvido/lido. O autor propõe que a escrita é um modo de enunciação heterogêneo, em que essas representações sulcam constitutivamente o enunciado.

Tais dinâmicas contribuem para as (re)configurações identitárias no que tange à escrita (em geral) e à escrita acadêmica (de modo específico) dos(as) acadêmicos(as). Mas é sobretudo na universidade que os acadêmicos vão configurar suas representações de escrita acadêmica de modo mais direto, deliberado e sistemático. Na dissertação de mestrado, analisamos detidamente os vários tipos de documentos acima citados, incluindo quatro manuais de escrita acadêmica, os quais seriam responsáveis pela constituição - ao menos por uma parcela considerável - discursiva e identitária dos(as) acadêmicos(as) da graduação com relação à escrita (acadêmica), objeto principal deste estudo. Eles teriam caráter formativo na trajetória acadêmica desses estudantes.

Simultaneamente a processos não subjetivos de individuação, buscamos reconhecer as diversas formas de inscrição da subjetividade nos resumos desses textos acadêmicos resultantes do TCC, compreendendo a subjetividade a partir da perspectiva dialógica do Círculo de Bakhtin, em que esta é concebida como sendo socialmente constituída. Para isso, propomos: analisar características estilísticas dos resumos na relação com coerção, poder, movimentos da subjetividade e processos de letramento; buscar refletir sobre práticas de escrita no interior de um enquadre de autoridade e poder política e culturalmente definido.

Para realizar esses objetivos, lançamos mão de fundamentos teóricos extraídos da teoria dos Letramentos Acadêmicos (STREET, 2014; 2010; LEA; STREET, 2014). A concepção de escrita adotada é a do modo heterogêneo de constituição da escrita, conforme Corrêa (1997), entre outros que embasam uma perspectiva enunciativa de estudo da escrita (CHACON, 1995; DAHLET, 2006; 2002; JUNG; SALEH, 2011; SALEH, 2017). Toda a orientação do trabalho é norteada pelos pressupostos da concepção dialógica da linguagem, conforme estabelecidos pelo Círculo de Bakhtin (BAKTHIN, 1997; 2002; 2006), bem como buscamos um fundamento 
para a investigação sobre a presença do sujeito na enunciação de uma perspectiva enunciativa da linguagem (BENVENISTE, 1989). Sobre a concepção de estilo adotada, nos valemos dos pressupostos elaborados por Bakhtin, (1997) e Signorini (2010).

O lócus de pesquisa é uma instituição de ensino superior pública estadual e os trabalhos são pertencentes a acadêmicos(as) dos cursos de Licenciatura em Letras Português/línguas estrangeiras e respectivas literaturas. O corpus da pesquisa está constituído por 46 resumos de TCCs defendidos em 2018, sendo 29 artigos, 13 monografias e quatro ensaios, distribuídos em três principais áreas: Ensino de Línguas, Linguística e Literatura. Pode-se observar interfaces entre as áreas das quais podem ser desdobradas algumas subáreas, tais como análise do discurso, pragmática, sociolinguística, semiótica, estudos identitários, estudos culturais, estudos de gênero, estudos do romance. Também encontramos subáreas com foco no ensino de línguas estrangeiras (inglês, espanhol e francês) e ensino de libras, com uma parcela significativa de trabalhos interdisciplinares: Literatura/ensino, Linguística/ensino, Literatura/Filosofia. Este lócus foi selecionado devido a relações prévias estabelecidas pelo pesquisador com a instituição, sendo essa uma instituição de ensino superior que apresenta um papel representativo e de certo impacto na comunidade, formando diversos profissionais na região dos campos gerais.

Nesse sentido, nas seções a seguir, apresentamos nossos pressupostos teórico-metodológicos, em que discutimos fatores constitutivos do enunciado, gêneros do discurso e enunciação, estilo e poder, e responsividade; depois, letramentos acadêmicos enquanto prática social que se efetua a partir de uma estrutura de autoridade política e culturalmente situada; por fim, expomos a metodologia da pesquisa e desenvolvemos a análise dos resumos, e tecemos nossas considerações finais.

\section{Fatores de CONSTItUIÇÃo do enUNCiAdo}

Segundo Bakhtin (1997), exercem influência na estrutura de um enunciado o interlocutor, aspectos de orientação axiológica e aspectos ideológicos. Não há enunciado sem acento de valor ou sem interlocutor. Esses fatores determinam o enunciado desde seu interior. O "para quem" é constitutivo do enunciado, tanto quanto fatores ideológicos e de poder. ${ }^{1} \mathrm{~A}$ influência na constituição do enunciado se dá, não somente, no plano do objeto de sentido do discurso: incide também no plano estilístico e composicional, de modo que por poder entendemos aquilo que influencia de forma dominante (seja de modo consciente, seja inconscientemente) a constituição de um enunciado, determinando-o desde um enquadre de autoridade política e culturalmente definido (STREET, 2014).

\footnotetext{
${ }^{1}$ Nos referimos aqui ao poder institucional (regulamentação da escrita) e ao poder vinculado às práticas de letramento (as quais abarcam processos institucionais, tanto quanto relacionam-se a cada curso, cada disciplina e mesmo a cada professor).
} 
Este enquadre constitui aquilo que o Círculo (BAKHTIN, 2006) denomina situação social imediata, a qual se define por dois horizontes, o horizonte social imediato (situação histórico-social micro) e o horizonte social mais amplo de um dado grupo social (situação histórico-social macro), em que macro/micro se interpenetram dialeticamente, vindo a refletir dialogicamente nos enunciados. Essa relação entre a situação social imediata e o enunciado não se dá de modo neutro, mas sempre a partir de uma estrutura de autoridade (institucional) e poder política e culturalmente definidas, sobretudo a partir da perspectiva do modelo ideológico de letramento (STREET, 2014; 2010). Esses modelos de letramento, jamais neutros ou meramente técnicos, funcionam produzindo identidades, as quais são configuradas e constituídas pela orientação que define esses programas de letramento, acadêmicos ou não.

Sendo o enunciado o ponto onde a vida penetra na linguagem e a linguagem penetra na vida, o enunciado é também o ponto de convergência e de cruzamento do estilo individual do gênero e dos traços da individualidade do locutor - seja explicitamente por meio daquilo que Benveniste (1989) descreve como aparelho formal da enunciação, seja por meio de outros procedimentos, como a instanciação de uma lógica da organização e do recorte (SIGNORINI, 2010), os quais são, também, reflexos de processos de letramento.

Para Benveniste, todavia, a (inter)subjetividade está instaurada na própria língua, no "aparelho formal da enunciação" (BENVENISTE, 1989, p. 81), nas coordenadas de pessoa, tempo e espaço. O grande mérito de Benveniste foi mostrar que a subjetividade está presente mesmo nas relações gramaticais, de natureza formal. Trata-se, além disso, de reconhecer a subjetividade como organizadora das relações formais da língua. Desse modo, concebemos a noção de autor por meio da concepção de agentividade (SIGNORINI, 2010), um vetor, dentre outros vetores atuantes em um texto, o qual instanciaria tanto estilos tidos como neutros quanto estilos pessoais, neste caso, individualidades sob o efeito de processos de letramento vigentes no interior do curso.

Quanto aos estilos, na superfície textual, seria preciso falar em efeitos de subjetividade e efeitos de objetividade (produção de sentidos) como estratégias e recursos discursivos que constituiriam os textos acadêmicos, não apenas concebê-los de maneira essencializada, como se houvesse, intrínseca à língua/gênero, alguma objetividade ou subjetividade que lhe fosse inerente. Algumas estratégias linguístico-discursiva produzem efeitos de objetividade, enquanto outras são mais propícias a efeitos de sentido de pessoalização do discurso.

\section{Discurso e ENUNCIAÇão ESCRITA}

Todo e qualquer uso da linguagem se dá na forma de gêneros, desde as conversas do cotidiano até os romances com centenas de páginas. Todos os nossos enunciados, segundo Bakhtin (1997, p. 302), "possuem uma forma padrão e relativamente estável de estruturação de um todo". Alguns são mais padronizados (documentos oficiais, por exemplo), outros mais 
maleáveis e flexíveis, mais abertos à criatividade (como os gêneros literários). De acordo com o autor, "na conversa mais desenvolta, moldamos nossa fala às formas precisas de gêneros, às vezes padronizados e estereotipados, às vezes mais maleáveis, mais plásticos e mais criativos".

O gênero é uma das condições de produção dos textos, no caso deste estudo o Artigo, a Monografia e o Ensaio, todos sob uma moldura em comum, o fato de consistirem em Trabalhos de Conclusão de Curso (TCC), independentemente do gênero: artigo/tcc, monografia/tcc, ensaio/tcc. São textos produzidos por ocasião de situação avaliativa no curso de graduação em Letras, como requisito parcial para a obtenção do diploma.

O Regulamento de TCC do curso se configura, neste estudo, como um dos diversos elementos de poder atuantes na escrita dos acadêmicos, o qual, dentre outros aspectos, atua limitando o número de páginas, mínimo e máximo de cada gênero, definindo os gêneros em que se pode realizar o TCC (Monografia, Ensaio, Artigo ou Material Didático), regulando o objeto de estudo, já que este prescreve que o TCC deva se constituir numa atividade acadêmica de sistematização do conhecimento sobre um objeto pertinente à profissão ou curso de graduação. O documento solicita: "Adequação formal ao gênero acadêmico". Não há, entretanto, uma definição ou caracterização do "gênero acadêmico", o que, pensamos, fica a encargo dos manuais de escrita acadêmica, de algumas disciplinas do curso, da ABNT, entre outros, tais como os enunciados congêneres já produzidos na esfera acadêmica, os quais, em boa medida, determinam a concepção de gênero dos acadêmicos, "enunciados lidos/ouvidos" que constituem o terceiro dos três eixos de representações dos escreventes sobre a escrita, anteriormente referidos (CORRÊA, 1997).

Os gêneros do discurso são elaborados nas diferentes esferas da atividade humana. A acadêmica, sendo uma das inúmeras esferas, elabora seus tipos relativamente estáveis de gêneros, tais como fichamento, diário de leitura, resumo, relatório, memorial, resenha, artigo acadêmico, monografia, ensaio, entre outros; e orais, como apresentação de seminários, debates, palestras, defesas de trabalhos, comunicações em eventos etc. Buscar entender as relações estilísticas e discursivas dos acadêmicos com e na escrita deve, necessariamente, passar pela compreensão de tais relações nos e pelos gêneros, mas também entender que estes gêneros estão sempre atrelados às relações de poder e autoridade, já referidas anteriormente.

Os gêneros discursivos, entre os quais se incluem os gêneros tipicamente acadêmicos, se distinguem por seu tema, estilo verbal e construção composicional, e tal distinção se instaura menos no âmbito formal do que no operacional. Esses três elementos não podem ser dissociados um do outro; apesar de possuírem características que os diferenciam, entrelaçam-se formando um todo: o gênero. Não há entre eles predominância de qualquer espécie (cf. BAKHTIN, 1997).

Os temas são gerados numa dada esfera discursiva correspondendo às condições de comunicação discursiva específicas dessa esfera, como descrito na introdução deste estudo 
quando nos referimos às áreas dos TCCs. ${ }^{2} \mathrm{O}$ estilo corresponde aos recursos lexicais, fraseológicos e gramaticais, do mesmo modo que o tema e a construção composicional emergem de uma esfera discursiva. Por construção composicional, se entende os contornos globais do gênero, o que possibilita seu reconhecimento, não sendo, porém, o que define sua completude. Esses três elementos, cabe destacar, são indissociáveis e, juntos, vão compor a totalidade do gênero, íntima e constitutivamente vinculado ao evento concreto de comunicação de que se originam. Não estão pré-dados, são co-constituídos tanto por processos subjetivos, quanto socioculturais, históricos e políticos, por isso relativamente estáveis.

Gênero e enunciado são conceitos complementares, pois os gêneros do discurso nada mais são do que formas típicas do enunciado que lhe conferem um caráter genérico; não são, entretanto, termos intercambiáveis. Trata-se de uma relação que, grosseiramente, poderia ser definida como do geral para o particular e vice-versa: o gênero é uma potencialidade que se realiza no enunciado e este (re)alimenta o gênero. Nessa direção é que concebemos cada TCC como um único enunciado em sua totalidade.

Segundo Bakhtin (1997, p. 286), os gêneros do discurso e o tipo a que pertencem são as correias de transmissão entre a história da sociedade e a história da língua: "Em cada época de seu desenvolvimento, a língua escrita é marcada pelos gêneros do discurso". O enunciado, tal como definido pelo autor, é a única unidade real da comunicação verbal, não as palavras, não a oração, as quais são unidades da língua e possuem apenas uma entonação gramatical. A expressividade que ecoa na palavra é um reflexo da expressividade do gênero; a entonação gramatical nada tem a ver com a expressividade, uma oração somente no todo do enunciado é que atinge uma entonação expressiva.

Não há análise isolada do enunciado que se sustente do ponto de vista dialógico. Todo enunciado, ao pertencer a uma cadeia de enunciados como um elo inalienável, dialoga irremediavelmente com todos aqueles que o precederam, os emanados pelo próprio locutor e os produzidos pelo outro, sabendo-se que todo enunciado pressupõe uma reação-resposta, isto é, uma atitude responsiva por parte do interlocutor. Essa dialogicidade incide não apenas no objeto de sentido do discurso, como opera, também, no plano estilístico-composicional. Nisso consiste a especificidade de nossa análise: observar de que modo o enunciado reflete, no plano estilístico, as relações de poder que concorreram para a sua produção.

O interlocutor, para Bakhtin (1997), tem um papel fundamental na composição do enunciado, influenciando em todos os aspectos, desde o temático e estilístico ao composicional. Mais do que isso, sem interlocutor não há enunciado. O fato de todo enunciado dirigir-se a um interlocutor, seja ele imaginado ou real, é um índice constitutivo e substancial do enunciado.

\footnotetext{
${ }^{2}$ Não que tema e área sejam elementos equivalentes, o vínculo se dá mais proximamente entre objeto de estudo e tema. Esses, em muitos casos, coincidem. Como os objetos de estudos relacionam-se às áreas é de se esperar que essas áreas condicionem, em certa medida, os temas. Estando essas áreas (Linguística, Literatura e Ensino de Línguas) já condicionadas por esfera que as abrange, a saber, a esfera de Licenciatura em Letras.
} 
A concepção de interlocutor varia conforme a área da comunicação verbal. Juntamente com a percepção e representação real do interlocutor, as quais efetivamente determinam o estilo do enunciado, existiriam, segundo o autor (BAKHTIN, 1997), formas convencionais e semiconvencionais de se dirigir aos leitores; essas formas estão intimamente ligadas à forma do gênero. ${ }^{3}$

Todo o processo discursivo supõe, por parte do locutor, uma antecipação das representações do interlocutor, sobre as quais se funda a estratégia do discurso. $O(a)$ interlocutor(a) influencia a estrutura do enunciado, mesmo não sendo um(a) avaliador(a), ${ }^{4}$ que determina, por autoridade institucional, o modo com que o enunciado deve estar constituído. Basta uma breve observação em enunciados elaborados por adultos e produzidos para crianças para se verificar como o "para quem" é constitutivo do enunciado.

As relações interlocutivas são, todavia, bastante dinâmicas e complexas. Bakhtin (1997) aborda o fator da pluridimensionalidade da interlocução, que significa que num mesmo enunciado pode haver várias camadas de interlocução e mesmo diferentes destinatários.

Os enunciados são, também, marcados irredutivelmente pela orientação axiológica dos sujeitos. A oração, como unidade da língua, não possui qualquer expressividade; o acento apreciativo só é possível pela presença do locutor na língua: "a oração enquanto tal carece de expressão típica, é neutra” (BAKHTIN, 1997, p. 310). O autor postula a neutralidade lexicográfica da língua. Para ele, esta, enquanto sistema, não possui qualquer expressividade, apenas o contato entre língua e realidade provoca o "lampejo da expressividade" (BAKHTIN, 1997, p. 312). Quando isso ocorre, há enunciado, e onde há enunciado há sujeito, há estilo e há gênero do discurso. O estilo individual do enunciado se define, acima de tudo, por seus aspectos expressivos.

O acento apreciativo de um enunciado expressa a relação emotivo-valorativa do locutor com o objeto do seu discurso; pode também expressar o seu juízo de valor, ou mesmo juízos de valor alheios e tonalidades emotivo-valorativas que atravessam constitutivamente o enunciado. Para Bakhtin (1997), selecionamos as palavras de acordo com as especificidades de um gênero, as tiramos não da neutralidade lexicográfica do sistema da língua, mas de outros enunciados, durante o processo de elaboração de um enunciado. Escolhemos uma palavra de acordo com sua expressão típica, pertencente a um enunciado, acima de tudo, enunciados congêneres ao que estamos elaborando, pelo tema, pelo estilo e pela composição. A enunciação escrita se dá, portanto, sob as formas do gênero.

${ }^{3}$ No caso dos TCCs um dos vínculos mais próximos e fortes com o leitor são o título e o resumo, os quais estão ligados a formas convencionais de interlocução no espaço acadêmico, de modo mais ou menos estável e flexível.

${ }^{4} \mathrm{~A}$ figura do avaliador é apenas uma das figuras interlocutoras de um TCC. 


\section{ESTILO, GÊNERO E PODER}

Bakhtin (1997, p. 284) declara ser todo enunciado individual, "e por isso pode refletir a individualidade do falante (ou de quem escreve), isto é, pode ter estilo individual”. O estilo do gênero e o estilo individual se fundem no enunciado. Em circunstância alguma o locutor renuncia completamente à sua individualidade e à sua subjetividade: "ajusta-se ao gênero escolhido, compõe-se e desenvolve-se na forma do gênero determinado" (BAKHTIN, 1997, p. 202). Para utilizar os termos de Corrêa (1997, p. 185), quando se refere ao misto oral/falado e letrado/escrito, "tudo se trata de se colocar na perspectiva" da mixagem entre os estilos individuais e os estilos do gênero (BAKHTIN, 1997), encontrar esses lugares por meio de pistas linguísticas específicas.

O estilo do gênero é historicamente definido, ${ }^{5}$ mas também é definido por políticas de linguagem, as quais se definem por uma rede complexa de agenciamentos de poder (dentre eles os documentos oficiais do curso, o regulamento para TCCs, os manuais de escrita, a $\mathrm{ABNT}$ ) que operam regulando o que se pode tomar como o estilo do gênero. Isto é, pode-se tomar o estilo do gênero tanto de uma óptica diacrônica quanto sincrônica. O mais acertado seria compreender esses dois vieses simultânea e dialeticamente, uma vez que os gêneros estão continuamente se modificando. Neste estudo nos detemos na análise dos artigos/TCC, monografia/TCC e ensaio/TCC. Em um artigo/TCC teremos certas tendências, no artigo de periódico teremos outras, podendo haver alguns pontos de contato entre ambos, tendo-se sempre em mente que estilo, tema e construção composicional são indissociáveis um do outro no enunciado.

O estilo do enunciado, então, será definido segundo enquadres de poder situados. Não haveria, portanto, um estilo do gênero, podendo-se falar em estilos. Sejam eles quais forem, serão definidos a partir de enquadres de poder e autoridade politicamente situados. A partir de determinadas estruturas de autoridade, elementos de estilos pessoais, por exemplo, seriam aceitáveis. Por outro lado, dada a historicidade dos gêneros acadêmicos, objetividade e impessoalidade é que serão tomadas como características básicas desses gêneros.

Por estilos individuais devemos entender os diferentes modos com que se cruzam o(s) estilo(s) do gênero e o(s) estilo(s) individual(is) daquele que enuncia, trata-se das diferentes maneiras de instanciar a organização e o recorte (agentividade). Sempre em amálgama com o estilo do gênero e submetidas a uma estrutura de autoridade que constrange, para falar nos termos de nosso objetivo, estilisticamente o texto a partir de fórmulas legitimadas de prestígio, as quais vinculam-se não apenas ao prestígio em um dado grupo social, mas a uma estrutura

\footnotetext{
${ }^{5}$ Swales (1990) apresenta uma visão diacrônica do artigo científico; desenvolve um breve histórico do artigo científico (AC) nos últimos 300 anos, desde o estabelecimento do primeiro periódico científico "The Philosophical Transactions of the Royal Society", em 1665, até os artigos científicos atuais.
} 
de poder socialmente situada que determina construções que serão legitimadas e outras que estarão excluídas. Sendo, também, no caso do TCC, indicativos de processos de letramento.

Segundo Signorini (2010), agentividade e estilo estão intimamente ligados. Para ela, no estudo das práticas sociointeracionais, orais ou escritas, a questão da agentividade, e não a da autoria, tem sido colocada como mais produtiva para se compreender melhor as ações individuais e de grupo nessas práticas. Pois a noção de autoria estaria mais vinculada a uma individualidade monolítica, fonte única dos sentidos veiculados no texto, enquanto que a ideia de agentividade coloca a subjetividade como um dentre outros vetores atuantes no texto, ou, melhor dizendo, uma subjetividade que se constitui no agenciamento de diferentes estilos, vozes e valorações; não unívoca, mas plurivocal, pluriestilística, plurivalorativa.

Os estilos individuais devem então se expressar no interior mesmo e a partir dessas construções cristalizadas do gênero, não fora delas, correndo o risco de não serem reconhecidas como formulações legítimas, o que afetaria a legitimidade do próprio estudo realizado em um texto acadêmico. Essas construções, além de dizerem respeito à tipicidade do gênero, relacionam-se à variedade culta da língua. Desse modo, o reconhecimento da pluralidade de estilos individuais passa pela compreensão dos processos subjetivos e não subjetivos de individuações, os quais podem ser verificados nos textos por meio de pistas linguístico-discursivas.

Isso se dá de modo diferente para cada um dos gêneros. No corpus de resumos, entretanto, como veremos, não foram encontradas especificidades contundentes atreladas a um dos três gêneros em específico, nem em termos de extensão/volume, nem em termos de outros aspectos estilísticos.

Neste estudo pretendemos dar ênfase aos modos com que essas relações de poder se dão no recorte estilístico-composicional buscando observar como, mesmo enquadrados em uma moldura de poder - que se efetua por meio de manuais de escrita acadêmica, sistemas de normalização tais como a ABNT e o Regulamento do curso, discursos dominantes e hegemônicos sobre cientificidade e objetividade da escrita acadêmica, processos de letramento - se inscrevem as subjetividades nos textos acadêmicos analisados.

\section{ResPonsividade E ESTILO}

O estilo depende das concepções típicas de destinatário pertinentes a cada gênero e esfera discursiva e de como o locutor percebe seu interlocutor. A presença do interlocutor no discurso jamais é neutra; ao contrário, é fundamental e exerce influência determinante no estilo do enunciado, bem como nos aspectos temático e composicional.

Esta faceta do enunciado - a interlocução - está diretamente ligada ao conceito de responsividade. Esta é essencial quando se pensa o estilo dos textos acadêmicos, uma vez que determinados estilos podem ter uma maior adesão por parte dos(as) leitores(as) que, 
assim como o texto, têm sua identidade determinada por estruturas de poder. Formulações cristalizadas em estilos acadêmicos tendem a manter o vínculo com o poder a que elas se vinculam. Essas construções funcionariam por meio da "indexicalização das formas linguísticas e textuais a valores, identidades e comportamentos sociais dados como típicos, ou seja, como típicos d“a” comunidade científica, ou d "o" cientista” (SIGNORINI, 2017, p. 62), já que "onde há enunciado há sujeito" (BAKHTIN, 1997). Não raro, tudo se passa como se a relação entre estilo e figurações de subjetividades e poder fosse uma relação essencializada. O papel da análise, nesse sentido, seria o de desnaturalizar esses vínculos, desmistificando-os, uma vez que, segundo Barthes (1978, p. 11) “o poder está presente nos mais finos mecanismos do intercâmbio social."

Os estilos, desse modo, não são gratuitos ou meramente possuidores de valor estético; eles dizem da constituição do trabalho, mas, principalmente, de seu impacto no leitor. Já que um TCC artigo/monografia/ensaio é escrito para ser lido e, de alguma maneira, afetar o leitor, esses diferentes estilos, se por um lado dizem respeito à subjetividade de quem produz os textos acadêmicos e suas relações com a linguagem, por outro estão intimamente ligados à responsividade. Um texto acadêmico escrito em estilo objetivo produz determinados tipos de reação-resposta que, muitas vezes, não seriam produzidos se fosse escrito em estilo pessoal. Diferentes estilos produzem diferentes reações-respostas por parte de seus leitores. A questão aqui não é mais, somente, fazer ciência, mas considerar que leitores atingir e de que forma fazê-lo, o que conduz para a discussão do letramento ideológico e das estruturas de poder que legitimam a escrita acadêmica.

Estilos legitimados e mais reconhecidos poderão ter melhor responsividade, melhor acolhida por parte de determinado tipo de leitor. O contrário não seria menos verdade: quando os limites do gênero são "forçados", isso pode se refletir direta e positivamente numa parcela do leitorado de texto científico. Essas relações, todavia, são bastante dinâmicas e complexas.

Os outros, destinatários do enunciado, têm, portanto, um papel fundamental na estruturação do enunciado e em sua formulação. Não são ouvintes (leitores) passivos, mas participantes ativos da comunicação verbal: "Logo de início, o locutor espera deles uma resposta, uma compreensão responsiva ativa. Todo enunciado se elabora como que para ir ao encontro dessa resposta" (BAKHTIN, 1997, p. 321). Todo enunciado traz em seu bojo a presunção de uma reação-resposta que pode ser imediata (já-aqui) ou por vir.

Segundo o autor, um enunciado absolutamente neutro é impossível, pois acentos de valor diversos e contraditórios atravessam um mesmo enunciado; a neutralidade é uma característica pertencente apenas à língua do ponto de vista do sistema. Isso não significa que não se possam reconhecer, na escrita acadêmica, recursos linguístico-discursivos que poderiam ser tomados como "estilos neutros". A impessoalidade "pura" seria uma característica apenas da língua do ponto de vista do sistema.

Na próxima seção, discutimos a questão dos letramentos acadêmicos. 


\section{LETRAMENTOS ACADÊMICOS E GÊNEROS ACADÊMICOS}

Os Novos Estudos do Letramento concebem letramento como um conjunto de práticas sociais de uso da escrita com objetivos e em contextos específicos e compreendem letramentos acadêmicos como um conjunto de práticas sociais de uso da escrita no contexto universitário e em contextos escolares (STREET, 2014, 2010; KLEIMAN, 1995).

O trabalho com os gêneros do discurso em práticas acadêmicas ou escolares pode receber um encaminhamento autônomo ou ideológico. Na perspectiva autônoma, serão consideradas as habilidades individuais dos sujeitos, e o letramento será compreendido de modo genérico, ancorado nessas habilidades individuais, na escrita como mera técnica e no ato de ler como um processo neutro de decodificação de palavras. No modelo de letramento autônomo, o letramento ocorre por meio da linguagem sem contexto, do discurso autônomo e do pensamento analítico, solto, sem relação com o aspecto social: "apresenta o texto como autônomo, como se o significado estivesse inscrito nas palavras" (JUNG; SALEH, 2011, p. 19).

Na perspectiva ideológica, os gêneros do discurso aparecem em práticas de escrita situadas, ancoradas em contextos culturais e sociais específicos, isto é, um conjunto de práticas envolvendo a leitura e a escrita. Adotamos a perspectiva do modelo ideológico, pois o aprendizado da escrita ocorre quando se leva em consideração práticas concretas e sociais, as práticas letradas sendo concebidas como produto da cultura, da história e do discurso.

Desse modo, entendemos que práticas de letramento são práticas sociais de uso da escrita e da oralidade, dependentes dos contextos de uso, não podendo dissociar-se destes, nem ser tratadas como técnicas neutras, as quais poderiam ser transferidas de um contexto para o outro indiscriminadamente.

Para compreender a escrita do estudante de Ensino Superior, Lea e Street (1998) propõem três modelos distintos: 1) modelo das habilidades; 2) modelo da socialização; e 3) modelo do letramento acadêmico. $O$ primeiro modelo concebe a escrita como habilidade individual e cognitiva. Sob a abordagem do modelo da socialização, bastaria ao estudante conhecer as exigências de cada gênero para se apropriar dele; esse modelo "supõe que os discursos disciplinares e os gêneros são relativamente estáveis e que, tendo os estudantes dominado e entendido as regras básicas de um discurso acadêmico particular, estariam aptos a reproduzi-lo sem problemas." (LEA; STREET, 2014, p. 479). O modelo dos letramentos acadêmicos é o que melhor apreende a complexidade imbuída na escrita acadêmica, uma vez que "abrange tanto questões epistemológicas quanto processos sociais incluindo: relações de poder entre pessoas, instituições e identidades sociais." (LEA; STREET, 2014, p. 479).

No caso dos textos acadêmicos analisados, entendemos que estão enquadrados dentro de uma estrutura de autoridade e poder politicamente situadas, e não poderia ser diferente, já que, bem ou mal, procuram responder àquilo que é solicitado. Esta estrutura constrange/dirige a escrita dos acadêmicos a moldes pré-estabelecidos, os quais estão vinculados a discursos 
cristalizados sobre cientificidade e a processos institucionais de regulamentação da escrita. Nesse estudo, nos propomos a investigar como isso se dá do ponto de vista do estilo. Por outro lado, tais textos podem ser tomados como indicativos de processos de letramento.

\section{Metodologia da Pesquisa}

O corpus analisado consiste de amostra na qual se reflete o choque entre as forças coercitivas e as subjetividades, engendrando uma diversidade de arranjos e individuações estilísticas que caracterizam cada resumo. Mais adiante neste estudo, será possível verificar que as características apresentadas pelos resumos subsidiaram a instauração de agrupamentos distintos com base nos estilos.

Sendo este é um estudo discursivo da enunciação para buscar depreender algumas relações estilísticas e dialógicas dos acadêmicos de um curso de Letras com a escrita, frente a fatores coercitivos e de poder. A metodologia de pesquisa é qualitativa, do tipo documental, constituída por fontes de primeira mão, por se tratar de documentos que não receberam qualquer tratamento analítico anterior. Em uma pesquisa qualitativa se considera que há uma relação dinâmica entre "o mundo real e o sujeito, isto é, um vínculo indissociável entre o mundo objetivo e a subjetividade do sujeito que não pode ser traduzido em números. A interpretação dos fenômenos e a atribuição de significados são básicas no processo de pesquisa qualitativa" (PRODANOV, 2013).

A universidade não possui banco de dados destes trabalhos, portanto, eles não são disponibilizados ao público. A coleta de dados se deu a partir do contato que estabelecemos com a professora responsável pela disciplina de OTCC no ano de 2018, a qual possuía arquivados os TCCs defendidos no curso de Letras da universidade nos anos mais recentes e nos disponibilizou as versões em pdf dos textos, os quais nos foram enviados por e-mail. Para atender às exigências éticas de pesquisa, optamos por numerar os TCCs. A ordem da numeração não segue nenhum critério em particular. ${ }^{6}$

\section{ESTILOS DE APRESENTAÇÃO DO TRABALHO E DISCURSO}

Ao procedermos à análise dos resumos, atentamos, inicialmente, para as características de volume, pudemos observar que 20 dos resumos possuíam mais de 100 palavras, 20 deles possuíam mais de 200, cinco deles menos de 100 e apenas um apresentava mais de 300 palavras, sendo que nenhum critério explícito é estipulado pelo regulamento do curso, estando todos eles, também, dentro dos limites estabelecidos pela ABNT, que estabelece um

${ }^{6}$ Pesquisa aprovada pelo CONEP em 22/09/2019. CAAE: 15782819.0.0000.0105 
limite de 500 palavras para esse tipo de trabalho com o número máximo de 250 , no caso de artigo de periódicos.

Pudemos notar que esses resumos se distribuíam, sem qualquer regularidade, entre os ensaios, os artigos e as monografias. Foram encontrados resumos com mais de 200 palavras tanto entre os artigos quanto entre as monografias ou os ensaios, de modo que o volume dos resumos não divisava nenhuma regularidade concernente à composição de um dos três gêneros, especificamente. Apesar de o único resumo a apresentar mais de 300 palavras ter sido de uma monografia, um dos 5 mais curtos era, também, o resumo de uma monografia. Pelo fato de o artigo e o ensaio terem uma extensão mais curta do que a monografia, poderse-ia esperar que os resumos das monografias fossem os mais extensos, todavia, não foi o que observamos, já que os resumos mais curtos do corpus, todos com menos de 100 palavras, estavam entre as monografias.

Observadas as características de extensão dos resumos e relacionando-as à composição dos gêneros, passamos à verificação do uso das vozes verbais nesses resumos. Um padrão foi aí observado: dos 46 resumos, apenas três deles estavam escritos em primeira pessoa do singular, enquanto que os outros 43 apresentavam estratégias de impessoalização do discurso, com formas impessoais, no gerúndio, no particípio e em terceira pessoa do singular e do plural, aspecto esse que associamos aos requisitos de impessoalidade e objetividade do discurso acadêmico. Essas estratégias de despersonalização do discurso se verificam nos sujeitos do discurso nesses resumos, pois em 38 deles o sujeito do discurso é o próprio trabalho, em cinco o sujeito do discurso está na forma impessoal e em apenas três o sujeito do discurso é o próprio acadêmico autor do TCC.

Notamos nos resumos a presença de diversos papéis sociais, tanto os assumidos pelos acadêmicos, quanto aqueles que faziam circular no discurso (professor, escritor, cineasta, pesquisador, mãe, doula etc), além disso, verificamos a existência de diferentes vozes sociais, veiculadas em paráfrases, citações ou referências, além da presença de heterogeneidade não mostrada e das vozes dos próprios autores dos textos dialogicamente encerradas no texto.

Foi, todavia, observando as caraterísticas estilístico-composicionais dos resumos, o modo com que estavam constituídos, a presença de elementos básicos, presentes em todos eles, tais como objetivo e objeto de estudo, metodologia, embasamento teórico, resultados, que começamos a perceber que havia diferentes modos de realizar esses elementos nos resumos. Reconhecemos algumas particularidades, como o fato de alguns resumos apresentarem a motivação de pesquisa, enquanto que outros não e o fato de alguns apresentarem miniresumos - de uma obra - dentro do resumo, característica dos resumos da área de Literatura. Diferentes estilos de desfecho, diferentes modos de apresentar os resultados - de forma mais ou menos explícita, mais ou menos direta -, diferentes maneiras de organizar os elementos essenciais do resumo. Alguns resumos indicavam a estrutura do artigo/ensaio/monografia, enquanto outros apontavam para os passos da pesquisa, fazendo isso de modos mais ou menos explícitos, 
valendo-se ora de índices específicos, ora de procedimentos acessórios. Formulações diversas que resultavam em diferentes estilos de construção global dos enunciados.

Ao percebermos esses modos diferentes de realizar os elementos básicos dos resumos, pudemos depreender alguns padrões estilísticos, os quais organizamos em agrupamentos distintos. Para o presente estudo apresentamos os padrões encontrados nos diferentes modos de apresentação do objetivo do estudo. Desse modo, dividimos os resumos em dois grupos, com base no estilo de apresentação do objetivo do estudo nos resumos: Grupo 1 - Formulações diretas e Grupo 2 - Formulações preambulares. Trata-se de caraterísticas estilísticas que dizem respeito à construção global dessas enunciações. Constituem formulações diretas todas aquelas construções que apresentam o objetivo do trabalho no início do resumo, já a partir da primeira construção, de forma concisa, breve e direta, em que se observa a utilização de recursos linguísticos similares. As formulações preambulares, por sua vez, consistem de todas aquelas construções que se delongam a expor o objetivo do estudo, a apresentação do objetivo vem precedida de uma construção mais ou menos extensa. Apresentam, também, segmentos constituídos por enunciações que se intercalam, efetuando uma suspensão no fluxo da enunciação. Este último grupo encontra-se em flagrante contraste com a larga maioria dos resumos, compondo uma parcela de $26 \%$, enquanto que o Grupo 1 consiste em $74 \%$ de um total de 46 TCCs.

Tomamos essa maior incidência do estilo direto como um reflexo contundente das forças de estabilização do discurso acadêmico, que operam as coerções relativas a uma estrutura de poder e autoridade. Recomenda-se, prioritariamente, o uso de estratégias diretas de exposição dos resultados, do objeto de estudo, da metodologia, do referencial teórico, com o máximo de objetividade, neutralidade e impessoalidade possível. Sendo indicativos não tanto de discursos acadêmicos hegemônicos, mas, sobretudo, de processos de letramento, já que, sob certo ponto de vista, os TCCs podem ser tomados como reflexo de processos de letramento na universidade.

Nesse grupo, preponderam recursos de impessoalização do discurso. Tais estratégias refletem dialogicamente o que apregoam os discursos dominantes hegemônicos sobre a escrita acadêmica, presentes em diversos manuais de escrita acadêmica, bem como em documentos oficiais de normalização do estilo acadêmico e sites pela internet. ${ }^{7}$

\footnotetext{
${ }^{7}$ Segundo o site "pós-graduando" destinado a orientar estudantes de pós-graduação sobre diversos assuntos relativos à pós-graduação, entre os dez erros mais comuns na redação científica aparece em primeiro lugar o uso da "Linguagem pessoal“. Outros erros elencados são "Frases longas" e "Frases em ordem invertida”. Disponível em: https://posgraduando.com/dez-erros-comuns-na-redacao-cientifica/. Acesso em: 27 jun. 2020.
} 
Vejamos a primeira dessas categorias de "Estilos de Apresentação do Objetivo":

Quadro 34- Formulações diretas

\begin{tabular}{|c|}
\hline GRUPO 1 - FORMULAÇÕES DIRETAS \\
\hline $\mathrm{n}^{\circ} \mathrm{O} 2$ "O objetivo deste artigo é refletir sobre [...]" \\
\hline $\mathrm{n}^{\circ} 03$ "Este trabalho busca refletir acerca da [...]" \\
\hline $\mathrm{n}^{\circ}$ ○4 "A presente monografia tem como intuito apresentar uma análise e discussão [...]" \\
\hline $\mathrm{n}^{\circ}$ o8 "Este artigo propõe-se a analisar [...]" \\
\hline nº 09 "Este trabalho de conclusão de curso visa a [...]" \\
\hline $\mathrm{n}^{\circ} 10$ "Este trabalho busca estudar a $[\ldots]$ " \\
\hline $\mathrm{n}^{\circ} 11$ "Este artigo tem como objetivo principal analisar as [...]" \\
\hline $\mathrm{n}^{\circ} 12$ "O presente artigo tem por objetivo apresentar a [...]" \\
\hline $\mathrm{n}^{\circ} 14$ "O presente trabalho pretende apontar [...]" \\
\hline $\mathrm{n}^{\circ} 15$ "Este trabalho tem por objetivo mostrar a $[\ldots]$ " \\
\hline $\mathrm{n}^{\circ} 17$ "O objetivo desse trabalho é apresentar resultados de uma pesquisa [...]" \\
\hline $\mathrm{n}^{\circ} 20$ "Este artigo revela os [...]" \\
\hline $\mathrm{n}^{\circ} 21$ "O presente artigo tem como intuito promover uma análise a partir da [...]" \\
\hline $\mathrm{n}^{\circ} 24$ "Este artigo tem por objetivo apresentar [...]" \\
\hline $\mathrm{n}^{\circ} 25$ "O propósito deste artigo é analisar as [...]" \\
\hline $\mathrm{n}^{\circ} 26$ "O presente estudo $[\ldots]$ aborda o $[\ldots]$ " \\
\hline $\mathrm{n}^{\circ} 27$ "O presente trabalho pretende refletir sobre as [...]" \\
\hline $\mathrm{n}^{\circ} 28$ "O presente trabalho visa expor e discutir uma [...]" \\
\hline $\mathrm{n}^{\circ} 29$ "O presente trabalho de conclusão de curso procura fazer uma breve análise da [...]" \\
\hline $\mathrm{n}^{\circ} 30$ "Neste artigo, foram analisados os [...]" \\
\hline $\mathrm{n}^{\circ} 31$ "O presente artigo pretende analisar o [...]" \\
\hline $\mathrm{n}^{\circ} 32$ "O presente trabalho tem o objetivo de..." diversidade de gênero currículo \\
\hline $\mathrm{n}^{\circ} 33$ "O artigo propõe $[\ldots]$ ao abordar o [...] expor..." \\
\hline $\mathrm{n}^{\circ} 34$ "O seguinte trabalho analisa o [...]" \\
\hline 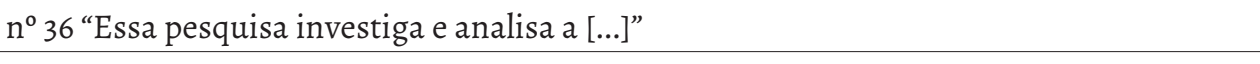 \\
\hline $\mathrm{n}^{\circ} 37^{\text {"O }}$ presente artigo irá tratar sobre [...]" \\
\hline $\mathrm{n}^{\circ} 38$ "Esta pesquisa tem como o principal objetivo investigar a [...]" \\
\hline $\mathrm{n}^{\circ} 39$ "Neste artigo pretendo analisar o [...] e discutir as [...]" \\
\hline $\mathrm{n}^{\circ} 40$ "Neste trabalho observa-se como é [...]" \\
\hline$n^{\circ} 41$ "Este trabalho apresenta uma pesquisa [...]" \\
\hline
\end{tabular}


conclusão

\begin{tabular}{|l|}
\hline \multicolumn{1}{|c|}{ GRUPO 1 - FORMULAÇÕES DIRETAS } \\
\hline$n^{\circ} 42$ "O objetivo deste artigo é [...]" \\
\hline$n^{\circ} 43$ "Este trabalho tem como objetivo central a análise de [...]" \\
\hline$n^{\circ} 44$ "O presente artigo pretende analisar o [...]" \\
\hline$n^{\circ} 45$ "Este artigo apresenta as [...]" \\
\hline$n^{\circ} 46$ "Este trabalho tem como objetivo analisar [...]" \\
\hline
\end{tabular}

Fonte: Elaborado pelo autor.

Dos 46 resumos, 34 iniciam com a apresentação do objetivo da pesquisa no primeiro enunciado, logo, com as primeiras palavras do resumo. A característica principal dessas construções consiste em serem constituídas por períodos breves e bastante curtos, alguns com apenas três elementos lexicais, como no resumo do TCC n 33 "O artigo propõe...". De início, satisfaz a expectativa do leitor quanto ao objetivo do estudo, seja ele analisar, investigar, apresentar, refletir, propor, observar, tratar sobre, refletir, expor, discutir, promover, apontar, revelar, buscar refletir sobre um objeto determinado etc. As expectativas quanto à apresentação do objetivo do trabalho e daquilo que, comumente, se espera de um resumo acadêmico, são imediatamente preenchidas. Trata-se de um número bastante representativo de textos acadêmicos onde atuam fatores geradores de estabilização.

O fato de $74 \%$ dos resumos iniciarem valendo-se de recursos linguísticos semelhantes se deve, dentre outros motivos, a que a objetividade, a clareza, a concisão e a diretividade são consideradas como características principais desses gêneros. Construções não literais são largamente evitadas. Segundo Dornelles (2006), isso ocorre para evitar um grau de ambiguidade que poderia demandar a leitura de todo o artigo ou de parte dele para tentar desfazê-la, o que invalidaria a própria finalidade do resumo.

Esses estilos de formulação ecoam também enunciados congêneres os quais têm em comum com esses o estilo e a construção composicional. Dessa forma estabelecem-se relações dialógicas que atualizam e remetem a esses estilos, caracteristicamente componentes de resumos de artigos, monografias e ensaios acadêmicos, instaurando assim processos interlocutivos e dialógicos vinculados a essas esferas em que esses estilos de enunciados costumam circular. Incialmente, a partir do recorte estilístico e composicional, em seguida, por recortes temáticos próprios dessas esferas.

No aspecto em análise, não há muita dificuldade em enfileirar esses resumos na mesma categoria, uma vez que as construções seguem todas o mesmo padrão, com pequenas alterações no âmbito lexical e diferenças intracláusula (no interior do continuum da enunciação) ínfimas, como iniciar o trabalho como a escolha do item lexical para iniciar a construção, que lhes conferem conotações de sentido e orientações axiológicas particulares. 
Vejamos agora o Grupo 2:8

Quadro 35- Formulações preambulares

\section{GRUPO 2 - FORMULAÇÕES PREAMBULARES}

$\mathrm{n}^{\circ}$ or "Clarice Lispector destaca-se na literatura brasileira por fazer uso de discursos que abordam questões profundas do interior do ser e, para isso, segundo Benedito Nunes (1995, p. 13), utiliza o "monólogo interior, a digressão, a fragmentação dos episódios, que sintonizam com o modo de apreensão artística da realidade da ficção moderna”. Fluxo de consciência é o nome dado para essa maneira de perscrutar o interior das personagens, revelando ao leitor elementos extremamente intimistas e pessoais, como pensamentos, memórias, digressões, indagações, etc. É a partir desse foco que analiso $[. .]$.

$\mathrm{n}^{\circ} 05$ "De uma perspectiva, uma realidade linguística viva e heterogênea. De outra, uma ideologia que tenta enquadrá-la em um modelo fixo e normativo. Esse conflito linguístico, há muito tempo presente na sociedade, se encontra também nos meios mais atuais de comunicação, como o Facebook. Neste espaço, percebe-se uma preocupação excessiva de uns com supostos erros de língua na fala/escrita de outros, o que se evidencia por certa liberdade de expressão, que permite a reprodução/aceitação acrítica de ideologias. Diante dessa problemática, o presente trabalho tem por objetivo investigar [...]".

$n^{0} 06$ "Esta pesquisa exploratória de revisão bibliográfica foi motivada pela experiência da pesquisadora com alunos surdos inclusos na rede regular de ensino em uma escola estadual na cidade de Ponta Grossa, durante participação no Programa Institucional de Bolsa de Iniciação à Docência (PIBID) da Universidade Estadual de Ponta Grossa (UEPG), pelo curso Letras Português-Francês. Nesse contexto, elencou-se como objetivo geral compreender [...]"

n 07 "Jogar videogame é muito comum nos dias atuais, sendo uma atividade que se destaca no campo do entretenimento. Tendo em vista a popularidade dessa atividade, é importante observar as influências que a mesma exerce sobre a aprendizagem de certos conhecimentos, no caso deste trabalho, a aquisição da língua inglesa como língua estrangeira/segunda língua. Para investigar como os jogos de videogame propiciam um ambiente para a aprendizagem de línguas, selecionamos um jogo específico chamado RedDeadRedemption como objeto de estudo."

$n^{\circ} 13$ Joseph Campbell foi responsável por relacionar os conceitos da psicologia de Carl Jung com estudos sobre religião e mitologia, percebendo que a maior parte das grandes histórias contadas ao redor do mundo possui uma estrutura narrativa semelhante, denominando-a Jornada do Herói. Anos depois, um roteirista norte-americano chamado Christopher Vogler notou que alguns roteiristas de Hollywood tinham usado a estrutura mítica de Cambell em seus roteiros e que essa forma narrativa, de certo modo, garantira-lhes algum sucesso. Interessado nisso, concentrou seus estudos em Campbell e organizou um "guia" para escritores - principalmente para roteiristas de cinema - que passou a ser usado como uma "bíblia" para grande parte dos estúdios norte-americanos. Pensando nisso, meu objetivo com este trabalho foi selecionar um objeto específico de minha apreciação pessoal [...] mostrando que esse objeto [...] tinha [...]"

${ }^{8} \mathrm{Na}$ dissertação desenvolvemos uma análise mais detalhada de cada um dos resumos. 
conclusão

\begin{tabular}{|c|}
\hline GRUPO 2 - FORMULAÇÕES PREAMBULARES \\
\hline $\begin{array}{l}\mathrm{n}^{\circ} 16 \text { "Pensando nas questões de teoria literária, os conceitos de romance e, principalmente para este } \\
\text { trabalho, os conceitos de existencialismo e de hominização através do contato com o outro, será } \\
\text { analisado e estudado o [...]" }\end{array}$ \\
\hline $\begin{array}{l}\mathrm{n}^{\circ} 18 \text { "Considerando a presença de diversas marcas linguístico-discursivas e das memórias que } \\
\text { afetam o indivíduo e o tornam um sujeito que não é capaz de controlar totalmente suas escolhas } \\
\text { retóricas, acredita-se ser de extrema importância analisar dentro da sala de aula os diferentes textos } \\
\text { e as diferentes formas de tratamento dadas à informação dentro do gênero notícia, pois isso leva a } \\
\text { formar um aluno-leitor capaz de avaliar, ponderar, comparar e ter uma atitude crítica diante do texto. } \\
\text { O objetivo desta pesquisa é verificar [...]" }\end{array}$ \\
\hline $\begin{array}{l}\mathrm{n}^{\circ} 19 \text { "O presente trabalho trata-se de uma pesquisa que se encontra na área da sociolinguística, que } \\
\text { teve por objetivo investigar as [...]" }\end{array}$ \\
\hline $\begin{array}{l}\mathrm{n}^{\circ} 22 \text { "Este trabalho, por meio de apontamentos das diversas dificuldades na educação quanto à } \\
\text { inclusão escolar, oriundos da participação dos acadêmicos do Curso de Letras Português/Francês no } \\
\text { subprojeto PIBID/CAPES/UEPG durante os anos de } 2107 \text { e 2018, tem por objetivo apresentar a [...]" }\end{array}$ \\
\hline $\begin{array}{l}\mathrm{n}^{\circ} 23 \text { "A questão metodológica presente no contexto da prática pedagógica tem sido objeto de pesquisa } \\
\text { que visam a refletir a respeito do processo de ensino-aprendizagem. Este trabalho objetiva discutir } \\
\text { a [...]" }\end{array}$ \\
\hline $\begin{array}{l}\text { n } 26 \text { "O presente estudo, iniciado em } 2017 \text { como projeto de TCC, aborda o contexto histórico atual } \\
\text { sobre a reforma do Ensino Médio (EM). Na análise desta reforma, se dará destaque à história do ensino } \\
\text { da língua espanhola no Brasil e à luta pela valorização do ensino desta língua no currículo de nossas } \\
\text { escolas. Assim, objetiva-se analisar a [...]" }\end{array}$ \\
\hline $\begin{array}{l}\mathrm{n}^{\circ} 35 \text { "Com a implantação e implementação da política de educação inclusiva no Brasil muitos desafios } \\
\text { foram encontrados, entre eles o preparo e a formação do professor para atuar nesta realidade. } 0 \\
\text { presente artigo tem por obietivo levantar [...]" }\end{array}$ \\
\hline
\end{tabular}

Fonte: Elaborado pelo autor

O Grupo 2, no entanto, necessita de uma análise mais detida, por apresentar algumas variações de maior intensidade, ainda que o incluamos em um mesmo grupo. Nelas, a inscrição da subjetividade é bastante evidenciada. Para nos restringirmos aos limites do presente artigo, vamos apresentar algumas amostras mais representativas das relações entre poder e estilo.

A elaboração de formulações preambulares é um forte indicativo do movimento do sujeito no discurso como que "torcendo" o estilo dominante de formulações que predomina no grupo 1. Esse grupo se constitui de 11 resumos, aos quais não se aplica a regra de construção dos outros 35, mas isso ocorre de maneira distinta em cada um deles. É possível observar, contígua à presença da subjetividade, a atuação dos vetores coercitivos e de poder, construções que indexam formas reconhecidas e de prestígio, entrelaçadas a movimentos subjetivos de estilo. 
Em cinco deles $\left(n^{\circ} 16, n^{\circ} 19, n^{\circ} 23, n^{\circ} 26, n^{\circ} 35\right)$ há uma construção, relativamente breve, antecedendo o momento da enunciação do objetivo do trabalho, conforme abaixo:

$\mathrm{n}^{\circ} 23$ A questão metodológica presente no contexto da prática pedagógica tem sido objeto de pesquisa que visam a refletir a respeito do processo de ensino-aprendizagem. Este trabalho objetiva discutir a [...]

No resumo $n^{\circ} 23$, a construção preambular visa a expor que o objeto do trabalho tem sido já objeto de pesquisa, produzindo assim uma emolduração para os sentidos que serão produzidos na sequência. Trata-se de um segmento de contextualização, sentido que situa a pesquisa para então enunciar seu objeto de estudo. Esses resumos realizam uma contextualização de modo a indicar em que cenário a pesquisa está inserida. Primeiro situa-se a pesquisa, para então apresentá-la, diferentemente do que ocorre com os trabalhos do Grupo 1, que realizam esse movimento de forma direta.

O resumo $\mathrm{n}^{0} 22$ apresenta características semelhantes às do primeiro grupo, no entanto, optamos por não o colocar no mesmo grupo, pois apresenta uma peculiaridade em relação aos outros 36. O segmento é intercalado por uma construção curta:

$\mathrm{n}^{\circ} 22$ "Este trabalho, por meio de apontamentos das diversas dificuldades na educação quanto à inclusão escolar, oriundos da participação dos acadêmicos do Curso de Letras Português/Francês no subprojeto PIBID/CAPES/UEPG durante os anos de 2017 e 2018, tem por objetivo apresentar a [...]"

Processo de natureza marcadamente enunciativa, evidencia-se o movimento do sujeito na enunciação. É possível acompanhar a sua presença no fluxo da enunciação, e a mixagem entre o estilo do gênero e o estilo individual.

De acordo com Chacon (1996, p. 141) "o ritmo é o movimento de unidades que poderiam ser definidas temporalmente como durações e que, no campo da linguagem, se organizam formando sistemas que fazem entrecruzar-se as mais variadas dimensões linguísticas". Algumas dessas unidades rítmicas mais se caracterizam por suspenderem ou por interromperem o fluxo. No caso do resumo analisado, a intercalação produz a suspensão da formulação do objetivo.

Observa-se que este resumo se apresenta intercalado por uma construção mais extensa, a qual impõe uma suspensão menos discreta no fluxo rítmico do discurso. Esses procedimentos se efetivam por meio do uso, principalmente, da pontuação, no caso o uso da vírgula e outros sinais que, segundo Dahlet (2002, p. 37, ênfases da autora), "tem a função comum de segmentar o continuum escritural. Eles delimitam os sintagmas, separando-os, e os hierarquizam, indicando a natureza de sua relação. A ordem na qual aparece essa classe de sinais não é aleatória: ela remete a sua força de segmentaçãa". A pesquisadora toma esses sinais como sendo sinais de segmentação e ainda distingue uma segunda classe que ela denomina de sinais enunciativos, uma vez que participam do jogo enunciativo. Nesse grupo estão: [“”], [itálico], [travessão de 
diálogo], [letra de forma], [sublinhado], [:], [- -], [( )], [?], [!], [...]. Assim como Saleh (2011), defendemos, que há sinais predominantemente sequencializadores e sinais predominantemente enunciativos, uma vez que sempre há algo de enunciativo nos sinais de pontuação.

O interior das duas vírgulas, nos dois casos, é preenchido por segmentos que atribuem sentidos ao resumo estabelecendo interlocução, e, além disso, afetam o aspecto rítmico do discurso, obrigando o leitor a suspender, no ato de leitura, o sentido inicialmente promovido e que talvez fosse o esperado, para interpor um novo sentido que alterará a compreensão da enunciação como um todo. A pontuação opera uma "elipse" dos elementos lexicais, tornando a leitura mais fluida, assertiva e direta. Para Chacon (1996), é possível estabelecer uma relação entre ritmo, organização linguística e sentido; para o autor, o ritmo não se restringe ao metro. Falar de ritmo é também falar de sentido.

Trata-se de estratégias discursivas de apresentação não direta do objetivo, onde se percebe o uso das vírgulas como um dos recursos expressivos. Nos dois casos isso ocorre para, no primeiro, situar desde quando o estudo está em andamento e, no segundo, apresentar as experiências dos acadêmicos em subprojetos tais como o PIBID, ${ }^{9}$ bem como apresentar os apontamentos dos discentes concernentes ao lugar de onde provêm as questões da pesquisa.

Trata-se de dois movimentos marcadamente enunciativos de caráter apreciativo, onde se evidencia de forma marcada a presença da subjetividade e a copresença dos fatores coercitivos, uma vez que o acadêmico não abre mão da estrutura padrão de apresentação direta, mesmo que por meio de uma ruptura com esse estilo, seja essa quebra feita por meio de uma intercalação, ou pela interposição de uma mais ou menos extensa formulação preambular. Pode-se ver aí tanto a indexação a formas de poder e prestígio, quanto a atuação dessas mesmas forças coercitivas constrangendo o uso dos recursos estilísticos na escrita desse(a) acadêmico(a). No interior mesmo da apresentação do objetivo do trabalho, o escrevente insere apreciações específicas a essas apresentações.

Isso demonstra que o grupo das Formulações preambulares não é totalmente homogêneo no recorte estilístico dado, apresentando nuances, embora possuam todas um esboço semelhante, no plano global das construções. A amostra apresentada, apesar da semelhança com os outros 34 resumos, distingue-se pela intercalação, a qual opera postergando a apresentação do trabalho.

Como os resumos do Grupo 1, a apresentação do trabalho é feita logo no primeiro enunciado do resumo, no entanto, isso se dá de forma diferente, com os segmentos interpostos entre vírgulas. Desse modo, justificamos incluí-los no segundo grupo. São formulações, todavia, para as quais, se houvesse um conjunto maior de ocorrências, se poderia criar um terceiro grupo de Estilos de Apresentação do Objetivo: "Formulações por intercalações".

${ }^{9}$ Programa de docência desenvolvido pela própria instituição à qual o acadêmico produtor do texto está vinculado. 
Vejamos o resumo $n^{\circ} 18$ :

$\mathrm{n}^{\circ} 18$ "Considerando a presença de diversas marcas linguístico-discursivas e das memórias que afetam o indivíduo e o tornam um sujeito que não é capaz de controlar totalmente suas escolhas retóricas, acredita-se ser de extrema importância analisar dentro da sala de aula os diferentes textos e as diferentes formas de tratamento dadas à informação dentro do gênero notícia, pois isso leva a formar um aluno-leitor capaz de avaliar, ponderar, comparar e ter uma atitude crítica diante do texto. $\mathbf{O}$ objetivo desta pesquisa é verificar como os [...]"

De certa forma, as construções são semelhantes às dos 34 outros resumos. Os mesmos recursos ou recursos equivalentes de apresentação no estilo direto são utilizados (destacados em negrito). A questão é o momento em que isso é feito: posterior a procedimentos de contextualização, de localização da pesquisa e indicação da relevância, entre outros. Trata-se de formulações que visam a produzir uma moldura específica para a pesquisa, as quais denominamos formulações preambulares.

Temos aí outro caso de formulações preambulares, entretanto, nesse se tem uma construção bem mais longa que a dos resumos anteriormente analisados. Esse extenso segmento (ocupa 50\% da composição do resumo, uma vez que este tem 164 palavras no total e o preâmbulo 76) situa o estudo e o contextualiza no interior de uma compreensão sobre linguagem e sobre leitura, enfatizando a "extrema" relevância da temática abordada.

Uma das características típicas desses resumos com estilos preambulares é a retomada do período preambular. Em alguns casos sugere-se algo que permanece implícito na formulação preambular para, em momento subsequente, retomar de forma explícita e por meio de recursos discursivo-textuais diretos. Nos resumos $n^{\circ} 05, n^{\circ} 13$ e $n^{\circ} 26$, utiliza-se um recurso mais explícito e marcado textualmente para retomada do segmento preambular: trata-se do uso de anáforas textuais, as quais resgatam o referente por meio de índices específicos (BENVENISTE, 1989). Porém, como dito, os acadêmicos se valem também de recursos textuaisdiscursivos indiretos para realizarem essa retomada, a fim de vincularem aquela enunciação às subsequentes.

\section{No resumo $n^{\circ} 05$}

nº5 “De uma perspectiva, uma realidade linguística viva e heterogênea. De outra, uma ideologia que
tenta enquadrá-la em um modelo fixo e normativo. Esse conflito linguístico, há muito tempo presente
na sociedade, se encontra também nos meios mais atuais de comunicação, como o Facebook. Neste
espaço, percebe-se uma preocupação excessiva de uns com supostos erros de língua na fala/escrita
de outros, o que se evidencia por certa liberdade de expressão, que permite a reprodução/aceitação
acrítica de ideologias. Diante dessa problemática, o presente trabalho tem por objetivo investigar [...]". 
O acadêmico descreve um cenário de onde emergem diversos conflitos relativos à linguagem e, fazendo uso de um recurso anafórico - "Diante dessa problemática" -, situa sua pesquisa no interior dessa moldura que descreve, circunscrevendo um contexto específico para seu estudo. Evidencia-se o movimento da subjetividade nas escolhas discursivas desse(a) acadêmico(a), quando opta por apresentar um conflito numa formulação preambular antecedendo a apresentação do objetivo do trabalho.

Cabe destacar que o autor se vale de índices específicos de retomada de referente cotextual, como estratégia discursiva, não apenas como mero mecanismo de retomada textual. Há implicações estilísticas nessas opções entre recursos linguísticos possíveis para se realizar a transição entre o período preambular e a apresentação "direta” do trabalho.

O resumo $\mathrm{n}^{\circ} 13$ segue o padrão recorrente no grupo 2 , uma vez que uma etapa preambular é preposta à apresentação do objetivo do resumo; diferentemente, todavia, dos outros 43 resumos este apresenta ocorrência de $1^{a}$ pessoa do singular, bastante atípico, não sendo a regra para a esmagadora maioria: ${ }^{10}$

no 13 Joseph Campbell foi responsável por relacionar os conceitos da psicologia de Carl Jung com
estudos sobre religião e mitologia, percebendo que a maior parte das grandes histórias contadas
ao redor do mundo possui uma estrutura narrativa semelhante, denominando-a Jornada do
Herói. Anos depois, um roteirista norte-americano chamado Christopher Vogler notou que
alguns roteiristas de Hollywood tinham usado a estrutura mítica de Cambell em seus roteiros
e que essa forma narrativa, de certo modo, garantira-lhes algum sucesso. Interessado nisso,
concentrou seus estudos em Campbell e organizou um "guia" para escritores - principalmente
para roteiristas de cinema - que passou a ser usado como uma "bíblia" para grande parte dos
estúdios norte-americanos. Pensando nisso, meu objetivo com este trabalho foi selecionar um
objeto específico de minha apreciação pessoal [...] mostrando que esse objeto [...] tinha [...]"

$\mathrm{O}(\mathrm{a})$ acadêmico(a) vale-se de índices específicos para marcar o procedimento de retomada, "Pensando nisso", ao invés de fazê-lo por meio de recursos textuais-discursivos indiretos. Este segmento preambular apresenta uma característica que tende para a narrativa. $\mathrm{O}$ escrevente conta uma breve história sobre o conceito de uma estrutura narrativa recorrente em todas as histórias contadas ao redor do mundo, denominado de "Jornada do herói", em que são colocados em jogo papéis sociais distintos, inicialmente os do psicólogo e do estudioso de religião e mitologia, em seguida o de roteirista de cinema.

Note-se a natureza rítmica desse segmento preambular, o qual apresenta três movimentos distintos. Esse efeito é produzido pela conjunção de vários recursos linguísticos, sobretudo

\footnotetext{
${ }^{10}$ De um total de 46 resumos, apenas três são escritos em $1^{\text {a }}$ pessoa do singular, em todos os demais o sujeito desse enunciado é o próprio trabalho, ou apresentam-se na forma impessoal, sem sujeito, o que evidencia a atuação dos vetores coercitivos atrelados à impessoalidade. Nos três casos de uso da $1^{\circ}$ pessoa do singular, dialoga-se com discursos mais flexíveis, voltados para a pessoalização do discurso na escrita acadêmica.
} 
pelo uso da pontuação. Três pontos [.] instauram esses três movimentos na enunciação desse período preambular, até que se chegue à apresentação do objetivo do trabalho.

O primeiro movimento distingue-se por apresentar o responsável pelo conceito de uma estrutura narrativa comum a todas as histórias ao redor do mundo; o segundo movimento descreve o que ocorreu anos depois dessa descoberta, o interesse de um roteirista norte-americano por essa estrutura narrativa presente nos filmes de Hollywood e, por fim, o terceiro movimento trata sobre um livro, escrito pelo referido roteirista, que passou a ser considerado como uma bíblia para uma parcela dos estúdios norte-americanos.

Percebe-se que o ritmo do enunciado se apresenta indissociavelmente amalgamado aos sentidos. Produzindo sentidos. Constitutivo desses efeitos de sentido, em que o uso da pontuação se exerce entrelaçado com outros recursos de ordem discursiva e linguística. Para Chacon (1996), "o ritmo é necessariamente uma organização ou configuração do sujeito em seu discurso" (CHACON, 1996, p. 50). O ritmo pode também estar atrelado às relações de coercitividade e poder, refletindo instanciações não subjetivas de individuação, como é possível observar nos dados em análise.

Evidencia-se, de forma bem marcada, o movimento enunciativo na utilização do ponto, tanto no resumo $\mathrm{n}^{\circ} 05$ quanto neste último, assinalando marcas da presença do sujeito na enunciação, em um casamento feliz entre o estilo do gênero e o estilo individual, alterando-se reciprocamente, embora de maneiras distintas para ambos.

Observe-se que o sujeito se coloca no discurso, por meio da primeira pessoa do singular, colocando-se ele(a) próprio(a) como sujeito do estudo, "meu objetivo", "objeto específico de minha apreciação pessoal". Este objeto específico o filme "De volta para o futuro". Segundo Chacon (1996), ritmo, sentido e subjetividade são indissoluvelmente ligados entre si em toda a produção verbal; segundo ele, desde o seu fluxo até o seu produto final, que seria o enunciado, ou (como prefere) o texto.

Essas formulações, denominadas preambulares, tendem a anteceder por inteiro a apresentação do objetivo do trabalho, que se dá em muitos casos após o ponto, demarcando claramente o segmento preambular e a apresentação do objetivo do trabalho (com o restante das enunciações do resumo). Em alguns casos, elas são mais curtas (verificar os resumos $n^{\circ} 19$, $n^{\circ} 23, n^{\circ} 16, n^{\circ} 35$ ), em outros, menos discretas e mais extensas (como nos resumos $n^{\circ} 06, n^{\circ}$ $\left.18, n^{\circ} 05, n^{\circ} 13\right)$.

Em nossa análise, todavia, identificamos outros casos, em que há suspensão da formulação (na qual estão presentes os índices específicos de apresentação do objetivo do trabalho, já referidos anteriormente) tipicamente anunciadora do objetivo. Nessa ruptura, se intercalam segmentos que produzem sentidos variados, ora mais discretos (resumo $\mathrm{n}^{\circ} 26$ ), ora mais extensos (resumo $\mathrm{n}^{\circ}$ 22). A vasta maioria dos resumos utiliza-se de formulações diretas, no que tange ao recurso de enunciação do objetivo do trabalho (mesmo que antecedido de 
construção preambular). No que tange ao Grupo 2, percebe-se que apresenta pelo menos três tipos de formulações preambulares: formulações preambulares discretas $\left(n^{\circ} 16, n^{\circ} 19, n^{\circ} 23, n^{\circ}\right.$ $26, n^{\circ} 35$ ), formulações preambulares extensas ( $n^{\circ} 01, n^{\circ} 05, n^{\circ} 06, n^{\circ} 07, n^{\circ} 13, n^{\circ} 18$ ) e formulações preambulares por intercalação $\left(n^{\circ} 22, n^{\circ} 26\right) .{ }^{11}$ No que se refere à transição do período preambular para a apresentação do objetivo, seis o fazem por meio de recursos anafóricos e/ ou catafóricos ( $\mathrm{n}^{\circ}$ 01, $\left.\mathrm{n}^{\circ} 05, \mathrm{n}^{\circ} 06, \mathrm{n}^{\circ} 13, \mathrm{n}^{\circ} 16\right)$, o restante se vale de recursos linguístico-discursivos indiretos. Dos 11 resumos, nove deles marcam o desfecho da formulação preambular com um ponto, enquanto que apenas dois $\left(n^{\circ} 16, n^{\circ} 19\right)$ diluem a formulação preambular na apresentação do objetivo por meio da sutileza da vírgula.

\section{CoNSIDERAÇõES FINAIS}

Este estudo nos possibilita perceber a existência de alguns agrupamentos que se assemelham do ponto de vista estilístico. Estes incluem os três gêneros em análise, em que os autores se valem de estratégias discursivas não tão marcadas, adotando procedimentos acessórios para enunciar sua posição, o objeto de investigação, o objetivo do trabalho, a metodologia, entre outros aspectos. Esses trabalhos foram incluídos no grupo que denominamos de Grupo de Formulações Preambulares. Percebeu-se que, mesmo no Grupo 2, os acadêmicos não abrem mão das estratégias diretas de apresentação. A diferença é que esses recursos de apresentação do objetivo são adiados e preteridos em função de outros aspectos que o autor do resumo procura promover para aferir sentidos ao seu texto. Observamos no conjunto dos trabalhos que, se há ação de fatores geradores de estabilidade "em contraposição a uma escrita dita objetiva, supostamente descompromissada com a criatividade e o estilo" (SIGNORINI, 2010), concernentes a questões perpassadas pelo poder institucional e pelos discursos hegemônicos dominantes sobre escrita acadêmica, há, também, fatores mais criativos geradores de transformações.

Apesar de se constituírem dentro de uma estrutura de poder, são abertos às subjetividades que preenchem os enunciados com tonalidades dialógicas de ordem bastante diversa. Não foram encontradas regularidades muito significativas com relação aos gêneros de cada um dos resumos, seja como pertencentes a artigos, a monografias ou a ensaios. A maioria dos resumos do Grupo 2 corresponde a monografias, sete deles, enquanto quatro são resumos de artigos e um, apenas, de ensaio. Seria possível imaginar que os estilos de formulações preambulares seriam uma característica mais comum às monografias, todavia, outros resumos do

\footnotetext{
${ }^{11} \mathrm{O} \mathrm{n}^{\circ} 26$ pertence a duas categorias, tanto a de formulações preambulares por intercalações quanto a de formulações preambulares discretas. Como formulação preambular intercalada sugere uma apresentação do objetivo do trabalho "O presente estudo, iniciado em 2017 como projeto de TCC, aborda [...]”, o qual só será explicitado na sequência da enunciação, depois de outra expressão sugestiva que tomamos como catafórica do objetivo, "Na análise desta reforma", uma vez que não há nenhuma informação prévia que se estaria realizando uma análise da reforma (no título ou no resumo), a qual, apenas, posteriormente, será explicitamente enunciada “Assim, objetiva-se analisar a Lei 13.415/2017".
} 
corpus contradizem essa observação, pois os resumos mais curtos encontrados em todo o corpus pertencem a monografias. Essas formulações não estão restritas às áreas específicas, uma vez que ocorrem em todas as três áreas.

Destacamos, ainda, que os elementos estilístico-composicionais evidenciados neste estudo não só refletem a individualidade dos seus autores ${ }^{12}$ e o estilo dos gêneros, como são indicativos dos processos de letramento pelos quais os acadêmicos produtores dos textos passam, os quais em boa medida são encabeçados pela instituição, especificamente, o curso de Letras, mesmo não compreendendo a complexidade implicada no letramento desses estudantes, uma vez que não obtivemos informações pessoais dos produtores dos textos, por exemplo, se o curso de graduação pelo qual realizam o TCC se constitui como uma segunda licenciatura ou não, nem tivemos informações sobre os processos de letramento que constituíram cada acadêmico(a) previamente ao seu ingresso na instituição. No entanto, isto não minimiza as implicações que este estudo sobre o TCC na universidade pode ter para os letramentos acadêmicos. Uma vez que se concebam os dados observados enquanto indicativos de processos de letramento, é possível tanto iniciar um processo de reflexão relativo às práticas de ensino de produção textual na universidade, como inovar sobre a abordagem da redação científica, apresentando aos acadêmicos uma diversidade de estilos de enunciados, os quais podem servir como ponto de partida para práticas de escrita no ensino superior.

Não constituiu foco deste estudo esgotar a análise nem as discussões sobre a escrita dos TCCs, pois foram analisados apenas alguns aspectos específicos de pontos de vista das relações entre poder e estilo. Esta investigação consistiu apenas em um recorte de algumas questões que consideramos fundamentais para a análise dos TCCs numa perspectiva enunciativa, bem como para a análise de outros textos e outros gêneros do discurso naquilo que se relaciona com os letramentos acadêmicos.

\section{REFERÊNCIAS}

BAKHTIN, Mikhail. Estética da criação verbal. Tradução de Maria Emsantina Galvão G. São Paulo: Martins Fontes, 1997.

BAKHTIN, Mikhail. Questões de literatura e estética - A teoria do romance. Tradução de Aurora Fornoni Bernardini et al. São Paulo: Editora Hucitec, 2002.

BAKHTIN, Mikhail. Problemas da poética de Dostoiévski. Tradução de Paulo Bezerra. Rio de Janeiro: Forense Universitária, 2008.

BAKHTIN, Mikhail. Marxismo e filosofia da Linguagem. Tradução de Michel Lahud e Yara Frateschi Vieira. 12. ed. São Paulo: HUCITEC, 2006.

${ }^{12} \mathrm{Um}$ dos vetores de força atuantes nos textos (TCC). 
BARTHES, Roland. Aula: aula inaugural da Cadeira de Semiologia Literária do Colégio de França. 14. ed. São Paulo: Cultrix, 2004.

BENVENISTE, Èmile. Problemas de linguística Geral II. Tradução de Maria da Glória Novak e Maria Luisa Neri. Campinas: Pontes, 1989.

CHACON, Lourenço. Ritmo da escrita: uma organização do heterogêneo da linguagem. 1996. 389f. Tese (Doutorado em Linguística) - Instituto de Estudos da Linguagem, Universidade Estadual de Campinas, Campinas, 1996.

CORRÊA, Manoel Luiz Gonçalves. O modo heterogêneo de constituição da escrita. 1997, 435f. Tese (Doutorado em Linguística) - Instituto de Estudos da Linguagem, Universidade Estadual de Campinas, Campinas, 1997.

DAHLET, Veronique. A pontuação e sua metalinguagem gramatical. Rev. Est. Ling., Belo Horizonte, v. 10, n. 1, p. 29-41, jan./jun. 2002.

DAHLET, Veronique. A pontuação e as culturas da escrita. Filol. Lingüíst. Port., n. 8, p. 287314, 2006.

DORNELLES, Márcia dos Santos. 0 problema do gerúndio em resumos de artigos científicos uma contribuição para a revisão textual. 2006, $27 \mathrm{f}$.. (Especialização em Estudos Linguísticos do texto) Curso de Especialização em Estudos Linguísticos do Texto da Universidade Federal do Rio Grande do Sul. Porto Alegre, 1997. Disponível em: https:/www.lume.ufrgs.br/bitstream/ handle/10183/60546/000860264.pdf?sequence=1. Acesso em: 10 fev. 2020.

JUNG, Neiva Maria; SALEH, Pascoalina Bailon de Oliveira. Letramentos: concepções de escrita e pontuação. Línguas e Letras, v. 12, n. 23, p. 195-216, jul./dez. 2011.

KLEIMAN, Angela B. Os significados do letramento: uma nova perspectiva sobre a prática social da escrita. Campinas-SP: Mercado de Letras, 1995.

LEA, Mary R; STREET, Brian. O modelo dos "letramentos acadêmicos": teoria e aplicações. Filol. Linguist. Port. São Paulo, v. 16, n. 2, p. 477-493, jul./dez. 2014.

PRODANOV, Ernani Cesar de Freitas. Metodologia do trabalho cientifico: Métodos e técnicas da pesquisa e do trabalho acadêmico. 2. ed. Novo Hamburgo: Feevale, 2013.

SALEH, Pascoalina Bailon de Oliveira. A pontuação enunciativa e a configuração das instâncias narrativas em notícias infantis. D.E.L.T.A., v. 33, n. 4, p. 1177-1208, 2017.

SALEH, Pascoalina Bailon de Oliveira. Afinal, quem narra na narrativa infantil? Cadernos de Estudos Linguísticos, n. 47, v. 1 e 2, p. 175-185, 2005.

SIGNORINI, Inês. Estilo e agentividade na escrita. In: TFOUNI, L. V. (Org.). Letramento, Escrita e Leitura - Questões Contemporâneas. Mercado de Letras, 2010. p. 197-215.

SIGNORINI, Inês. Metapragmáticas da 'redação' científica de 'alto impacto'. Revista do GEL, v. 14, n. 3, p. 59-85, 2017. 
STREET, Brian. Letramentos sociais: abordagens críticas do letramento no desenvolvimento, na etnografia e na educação. Tradução Marcos Bagno. São Paulo: Parábola Editorial, 2014.

STREET, Brian. Dimensões "escondidas" na escrita de artigos acadêmicos. Perspectiva, v. 8, n.2, p. 541-567, 2010.

SWALES, John Michigan. Genre analysis: English in academic and research setting. Cambridge: Cambridge University Press, 1990.

Recebido para publicação em: 13 jul. 2020. Aceito para publicação em: $11 \mathrm{dez} .2020$. 